\title{
Eugeniusz Brzuska
}

Katedra Stosunków Międzynarodowych,

Społeczna Akademia Nauk, Łódź

\section{EUROPEJSKA POLITYKA SĄSIEDZTWA W KSZTALTOWANIU POGRANICZA UNII EUROPEJSKIEJ NA PRZYKLADZIE PAŃSTW POLUDNIOWEGO KAUKAZU}

\section{Wstęp}

Celem niniejszego artykułu jest próba ukazania Europejskiej Polityki Sąsiedztwa jako narzędzia oddziaływania na pogranicze Unii Europejskiej na przykładzie obecności Unii na południowym Kaukazie. Środowisko międzynarodowe dziś jest niezwykle bogate i dynamiczne. Charakteryzuje się szczególnie obecnością wielu podmiotów pozapaństwowych. Natomiast jednym z największych jego fenomenów jest powstanie, funkcjonowanie i rola Unii Europejskiej na współczesnej scenie międzynarodowej. Jej powstanie, funkcjonowanie i rola, jaką odgrywa w stosunkach międzynarodowych jest nową jakością współczesnych stosunków międzynarodowych. Unia Europejska z jej wyposażeniem prawnym, organizacyjnym oraz finansowym może być dziś uznana za aktora stosunków międzynarodowych. Ponadto, Unia jest dziś w posiadaniu poważnego narzędzia oddziaływania na środowisko międzynarodowe, w szczególności w odniesieniu do swojego pogranicza, a mianowicie Europejskiej Polityki Sąsiedztwa, którą Unia stworzyła w odpowiedzi na jej największe rozszerzenie, które nastąpiło w 2004 r. Jest to bardzo rozległe i wielowymiarowe narzędzie, w związku z tym trudne do ogarnięcia na kilku stronach tekstu. Dlatego też ukazano tutaj niewielki jej wycinek, a mianowicie rolę Unii jako aktora na południowym Kaukazie, którą Unia odgrywa dzięki wdrażaniu Europejskiej Polityki Sąsiedztwa w tym regionie. Analizie poddano wybrane komunikaty Komisji Europejskiej, wybrane dokumenty Komisji Europejskiej i krajów południowego Kaukazu oraz wybraną literaturę przedmiotu. W artykule broniona jest teza, że Unia Europejska może być aktorem sceny międzynarodowej w pełnym tego słowa rozumieniu, dzięki wdrażaniu Europejskiej Polityki Sąsiedztwa. Co ważniejsze, Unia jest coraz bardziej świadoma swojej roli oraz zadań i coraz odważniej na tej scenie występuje. Scena międzynarodowa dziś tym się charakteryzuje, że jest niezwykle dynamiczna i Unia Europejska wkracza na nią jako aktor coraz poważniejszy. Pytaniem na miarę początku wieku 
jest, w jaki sposób będzie się ona w tej roli sprawdzać oraz obok których aktorów będzie na tej scenie występować. Badacze są w tym miejscu raczej zgodni, że będzie w dużej mierze zależeć od samej Unii w sensie instytucjonalnym oraz od efektywności wdrażania przez Unię jej rozległej i ambitnej polityki, którą jest Europejska Polityka Sąsiedztwa

\section{Unia Europejska we współczesnym środowisku międzynarodowym}

Współczesne życie międzynarodowe charakteryzuje się olbrzymią dynamiką, a także bardzo skomplikowaną siecią powiązań poszczególnych jego uczestników. Przez uczestników stosunków międzynarodowych rozumie się tutaj podmioty zdolne do aktywności międzynarodowej, czyli do zmieniania i utrwalania w sposób zamierzony stanów środowiska międzynarodowego. Jednocześnie także podkreśla się, że pojęcie uczestnika oraz aktora uznaje się tutaj jako tożsame. Uczestnicy współczesnych stosunków międzynarodowych są zbiorowością bardzo liczną i niejednorodną. Jest to jedna z najbardziej charakterystycznych cech współczesnego środowiska międzynarodowego. Drugą bardzo charakterystyczną cechą jest wzrost znaczenia niepaństwowych uczestników (aktorów) na scenie międzynarodowej ${ }^{1}$.

Dzisiejszych uczestników stosunków międzynarodowych można podzielić na: państwa, narody, zbiorowe podmioty międzypaństwowe, zbiorowe podmioty międzyspołeczne, zbiorowe podmioty gospodarcze oraz prywatne i subpaństwowe podmioty krajowe. Państwa są niezmiennie uważane za najważniejszych, centralnych uczestników stosunków międzynarodowych, aczkolwiek rola pozostałych systematycznie wzrasta. Zwłaszcza należy mieć tutaj na uwadze zbiorowe podmioty międzypaństwowe. Są to trwałe związki państw, zorientowane w swej aktywności na realizację wspólnych interesów zbiorowości, którą stanowią. Mają one charakter międzynarodowy i publiczny².

Kolejną cechą charakterystyczną współczesnych stosunków międzynarodowych jest samo powstanie i funkcjonowanie Unii Europejskiej. Unia Europejska jest na tyle specyficznym tworem, że wymyka się definicjom. Łatwiej jest określić, czym Unia Europejska nie jest niż czym Unia Europejska jest. Idąc tym tropem należy stwierdzić, że Unia Europejska nie jest superpaństwem z jednej strony, natomiast nie jest też do końca tylko i wyłącznie organizacją międzynarodową. Dlatego też bardzo często w analizach dotyczących uczestników stosunków międzynarodowych jest podkreślana ta jej unikatowość i nie jest ona wymie-

${ }^{1}$ I. Popiuk-Rysińska, Uczestnicy stosunków międzynarodowych, ich interesy i oddziaływania, [w:] Stosunki międzynarodowe. Geneza, struktura, dynamika, red. E. Haliżak, R. Kuźniar, Warszawa 2006, s. 88.

2 Tamże, s. 94. 
niana ,jednym tchem" w szeregu z innymi organizacjami międzynarodowymi. Z drugiej strony nikt nie porównuje jej także z państwem³ ${ }^{3}$.

Unia Europejska w swej specyfice, a jednocześnie w swych rozmiarach i w stopniu zaawansowania procesów, które sama stworzyła jest środkiem ciężkości dla olbrzymiej ilości państw. Jest tak, ponieważ, jak już wspominano, jej rozmiary oraz zaawansowanie stopnia integracji spowodowały, że jawi się ona jako przykład nowego rodzaju układania się państw i to na wszystkich płaszczyznach, zarówno w sferze ekonomicznej, jak też i politycznej oraz strategicznej. Jawi się ona jako wzorzec funkcjonowania państw w przyszłości. Równocześnie także trudno spodziewać się, żeby przedsięwzięcie tej skali pozostawało bez echa na arenie międzynarodowej. Dlatego też Unia Europejska sama poszukuje swojej międzynarodowej tożsamości z jednej strony, a równocześnie poszukuje się punktów odniesienia dla niej samej. Pytanie, na ile Unia Europejska jest już definiowalnym graczem na scenie międzynarodowej jest jednym z najczęściej dzisiaj stawianych pytań badawczych przez samych polityków, a także przez badaczy stosunków międzynarodowych ${ }^{4}$.

\section{Unia Europejska jako aktor na scenie międzynarodowej}

Unia Europejska jest podmiotem, który reprezentuje siebie na arenie międzynarodowej za pośrednictwem swoich organów oraz przedstawicielstw w poszczególnych krajach. Posiada ona kompetencje do zawierania umów międzynarodowych zarówno z pozostałymi państwami, jak i z poszczególnymi organizacjami międzynarodowymi. Zostało to określone w „Postanowieniach wspólnych” Traktatu o Unii Europejskiej, a także w artykule 2 Traktatu o Unii Europejskiej5.

\section{Definiowanie ról w naukach społecznych}

W naukach społecznych nie ma jednej, uniwersalnej definicji roli społecznej. Na przykład antropologia podaje definicję roli społecznej jako system normatywnie określonych wzorów zachowań. Psychologia - system zachowań oczekiwanych od jednostki w związku z jej pozycją społeczną. Nauki historyczne zaś mówią o przejawach obiektywnych procesów historycznych.

W socjologii mamy niezwykle bogatą literaturę dotyczącą ról społecznych. Jest to w socjologii bardzo kluczowe pojęcie, które, jak się dość powszechnie przyjmuje, zostało przeniesione z literatury i teatru. Ponieważ pierwotne znacze-

${ }^{3}$ Tamże, s. 95.

${ }^{4}$ P. J. Borkowski, Polityka Sąsiedztwa Unii Europejskiej, Warszawa 2009, s. 7.

${ }_{5}^{5}$ Tekst Traktatu o Unii Europejskiej, [w:] Dokumenty europejskie, oprac. A. Przyborowska-Klimczak, E. Skrzydło-Tefelska, Lublin 1999. 
nie roli odnosi się do aktora występującego na scenie, który odgrywa swoją rolę właśnie. Wysnuwane są tutaj analogie w odniesieniu do ról społecznych. Rola aktora teatralnego wynika z zajmowanej przez niego pozycji, musi on trzymać się scenariusza oraz tego, co nakazuje mu reżyser. Aktor społeczny również zajmuje określoną pozycję, odpowiednikiem scenariusza są normy i standardy, których aktorzy społeczni muszą przestrzegać i do których muszą wzajemnie dostosowywać swoje reakcje ${ }^{6}$.

Piotr Sztompka także uważa, że pojęcie roli w socjologii wzięło się z metafory. Sztompka także pisze o przenoszeniu na życie społeczne spostrzeżeń dotyczących aktora na scenie teatralnej. I tak, polski socjolog pisze, że jedną z najistotniejszych cech roli $w$ teatrze jest to, że istnieje ona wcześniej niż podejmuje ją konkretny aktor, jest dla niego faktem zastanym, ponadto jest także faktem zewnętrznym, ponieważ aktor sam jej nie tworzy. Scenariusz wyznacza aktorowi szczegółowy sposób postępowania. Istotną metaforą jest także to, że aktor musi sobie swoją rolę przyswoić zanim będzie mógł ją zagrać. Istnieją także różne predyspozycje do ról różnego typu, na scenie występuje wielu aktorów, a poszczególni aktorzy grają w swoim życiu wiele ról. Gdy przeniesiemy to na teren życia społecznego, możemy dostrzec analogie we wszystkich pokazanych wyżej punktach odniesienia?.

Pojęcie roli jest także bardzo użyteczne w rozważaniach dotyczących relacji jednostki do systemu aksjonormatywnego, który narzuca kultura. Tutaj należy zaakcentować zależność roli i społeczeństwa, do której autor powróci poniżej, przytaczając poglądy Sztompki na temat zależności pomiędzy rolą a pozycją społeczną. Otoczenie społeczne, w którym żyje każdy człowiek jest bardzo złożone i pluralistyczne, co więcej, nie zawsze jest spójne. Dlatego też można tutaj mówić o pluralizmie pozycji społecznych i przynależności grupowych, a także o wielości kultur, z którymi styka się jednostka w wielokulturowym świecie i o wielości reguł, jakie wyznaczają jej działania w każdej pojedynczej roli lub, gdy pełni wiele ról równocześnie. Niespójność normatywnych oczekiwań prowadzi do antynomii i konfliktów w obrębie roli, konfliktów między rolami, a także wynikających w konsekwencji napięć, z którymi jednostka musi sobie radzić ${ }^{8}$.

\section{Klasyfikacja ról międzynarodowych państw i podmiotów niepaństwowych}

Bardzo rozpowszechnioną i ciekawą klasyfikacją ról międzynarodowych utworzył Kalevi Holsti. Zanalizował on deklaracje programowe najwyższych przedstawicieli kilkudziesięciu państw i wskazał na 17 ról międzynarodowych.

${ }^{6}$ M. Łoś, „Role społeczne” w nowej roli, [w:] O społeczeństwie i teorii spolecznej, red. E. Mokrzycki, M. Ofierska, J. Szacki, Warszawa 1985, s. 123.

${ }^{7}$ P. Sztompka, Socjologia, analiza społeczeństwa, Kraków 2002, s. 267.

${ }^{8}$ Tamże, s. 268. 
Są to następujące role:

1) bastion rewolucji - wyzwoliciel - podmiot czuje się zobowiązany do organizacji i przewodzenia różnym ruchom wyzwoleńczym poza granicami swojego kraju;

2) przywództwo w regionie - podmiot czuje się w obowiązku wziąć odpowiedzialność za cały region, z którym bardzo mocno się utożsamia;

3) opiekun w regionie - rola ta zakłada, że podmiot w sposób szczególny czuje się odpowiedzialny za to, co dzieje się w danym regionie, albo w danych kwestiach związanych z regionem i wtedy podmiot widzi się w roli przywódczej $\mathrm{w}$ danym regionie;

4) niezależność i aktywność - rola ta odnosi się w sposób szczególny do państw i dotyczy ich polityki zagranicznej. Państwo takie nie jest zainteresowane wchodzeniem w jakiekolwiek sojusze, prowadzi jednak własną aktywną politykę zagraniczną;

5) stronnik ruchów wyzwoleńczych - podmiot występujący w takiej roli nie czuje się wprost „organizacyjnie” odpowiedzialny za ruchy wyzwoleńcze, ale udziela im innego rodzaju wsparcia, takiego jak wsparcie moralne czy też polityczne;

6) agent antyimperialistyczny - podmiot $\mathrm{w}$ tej roli dostrzega imperializm jako swojego wroga i widzi swoją specjalną rolę w walce $\mathrm{z}$ nim;

7) obrońca wiary - podmiot widzący się w tej roli widzi siebie jako tego, który dba o czystość doktryny danej religii;

8) mediator - integrator - podmiot taki postrzega siebie w roli organizatora i prowadzącego mediacje i negocjacje pomiędzy podmiotami działającymi na forum międzynarodowym, a które są ze sobą skonfliktowane;

9) uczestnik podsystemu regionalnego - podmiot, który nakłada na siebie tę rolę widzi siebie jako budowniczego współpracy regionalnej;

10) wspierający rozwój innych państw - podmiot widzi siebie w roli tego, który wspiera rozwój państw słabo rozwiniętych;

11) pomost - podmiot spełnia rolę komunikatora i przekaźnika informacji pomiędzy podmiotami, które działają na scenie międzynarodowej, a które wywodzą się z odmiennych kultur;

12) wierny sojusznik - jest to rola mało aktywna, zakłada bardzo konsekwentne wspieranie przez dany podmiot polityki danego państwa;

13) dbający o swoją niezależność - jest to bardzo interesująca rola aktora, który czuje się absolutnie niezależnym na scenie międzynarodowej, kieruje się interesem tylko i wyłącznie własnej społeczności, popieranie celów innych podmiotów go nie interesuje;

14) dający przykład - jest to kolejna bardzo interesująca rola podmiotu na scenie międzynarodowej. Podmiot widzący siebie w tej roli najbardziej dba o swój prestiż na scenie międzynarodowe, chce on wywierać wpływ na środowisko międzynarodowe przede wszystkim poprzez siłę własnego prestiżu; 
15) budowniczy własnego potencjału - podmiot występujący w tej roli działa, co prawda, na forum międzynarodowym, ale jest zainteresowany przede wszystkim budową własnego potencjału;

16) izolator - podmiot realizujący tę rolę występuje na forum międzynarodowym tylko z przymusu, raczej izoluje się i stara się ograniczać swoje kontakty międzynarodowe;

17) protegowany - rola ta jest o tyle ciekawa, że podmiot w niej występujący powołuje się w większości przypadków na odpowiedzialność innych podmiotów i nie deklaruje jasno własnych celów, które chciałby osiągnąć na forum międzynarodowym ${ }^{9}$.

Holsti pisze też o rolach, które w jego opinii występują nieco rzadziej, choć są także niezwykle ciekawe. Są to role:

- obrońcy pokoju;

- agenta antysyjonistycznego;

- agenta antyrewizjonistycznego;

- języczka uwagi.

\section{Role Unii Europejskiej na scenie międzynarodowej}

W odniesieniu do problemu określenia funkcjonowania i znaczenia Unii Europejskiej jako aktora stosunków międzynarodowych chciano tutaj wykorzystać teorię ról międzynarodowych. Jeden z najbardziej klarownych i przejrzystych zestawów ról międzynarodowych odgrywanych w stosunkach międzynarodowych przez Unię Europejską opracował i przedstawił R. Zięba. Rola międzynarodowa odgrywana przez dany podmiot (danego aktora) to zorganizowany i celowy system oddziaływań danego aktora stosunków międzynarodowych na innego aktora tychże stosunków. W teorii stosunków międzynarodowych z reguły wyróżnia się trzy podstawowe typy ról dla organizacji międzynarodowych:

1) Rola instrumentu polityki zagranicznej poszczególnych państw członkowskich. Jest to rola czysto instrumentalna. Poszczególne państwa wykorzystują daną organizację do przeprowadzania wszystkich spraw istotnych dla danego państwa;

2) Rola areny międzynarodowej. Jest to rola międzynarodowego forum dla poszczególnych państw. Państwa na nim prowadzą konsultacje, uzgadniają łączące ich interesy, a także zawierają pomiędzy sobą porozumienia;

3) Rola niezależnego aktora w stosunkach międzynarodowych. Jest to rola aktora wpływającego w sposób samodzielny i niezależny na scenę polityczną.

${ }^{9}$ K. J. Holsti, National Role Conception in the Study of Foreign Policy, [w:] Role Theory and Foreign Policy Analysis, ed. S. Walker, Durham 1987, s. 9. W Polsce bardzo intensywnie problematykę tę badał przede wszystkim Ziemowit J. Pietraś, zob.: Z. J. Pietraś, Pojęcie i klasyfikacja ról międzynarodowych, Lublin 1989, s. 24. 
Role te są dzielone w zależności od dziedziny stosunków międzynarodowych, w której są odgrywane. I tak, organizacje międzynarodowe mogą odgrywać role polityczne, jak również ekonomiczne, militarne, humanitarne, kulturowe, a także inne ${ }^{10}$.

Na podstawie klasyfikacji Zięby można również wyróżnić role, które Unia Europejska odgrywa jako aktor stosunków międzynarodowych. Są one oparte o trzy obszary stosunków międzynarodowych. Unia Europejska, według tej klasyfikacji, odgrywa międzynarodowe role ekonomiczne związane przede wszystkim z rozwojem i integracją ekonomiczną, ale także jest to rola największego udziałowca w handlu światowym oraz rola jednego z największych dostarczycieli dwóch rodzajów pomocy, mianowicie pomocy rozwojowej oraz pomocy humanitarnej. Unia Europejska odgrywa także role jako aktor międzynarodowych stosunków politycznych. Unia występuje jako aktor polityczny działający w celu ochrony wspólnych wartości oraz zasadniczych interesów. Unia występuje także jako aktor dyplomatyczny. Rola ta jest odgrywana przez Unię Europejską na arenie bezpieczeństwa międzynarodowego. Unia działa na tym polu jako aktor umacniający pokój i bezpieczeństwo międzynarodowe. I wreszcie należy pamiętać o roli, jaką Unia Europejska odgrywa na scenie międzynarodowych stosunków kulturowych. Unia Europejska jest podmiotem unikalnym, stworzonym przez państwa europejskie. Ten jedyny w swoim rodzaju związek państw jest ukoronowaniem bardzo wielu wysiłków i koncepcji, które zmierzały do zbudowania jedności na kontynencie europejskim. Jedność ta zawsze miała bazować na dorobku cywilizacyjnym i kulturowym Europy, który został ukształtowany w Europie na bazie kultury greckiej, prawa rzymskiego, uniwersalistycznych idei chrześcijańskich, a także oświeceniowej świeckiej myśli humanistycznej. Można śmiało stwierdzić, że Unia Europejska ze swoją wizją kulturową i cywilizacyjną jest rdzeniem cywilizacyjnym Europy i potężnym ośrodkiem i promotorem cywilizacji europejskiej na świecie ${ }^{11}$.

A zatem uznawane role Unii Europejskiej na scenie międzynarodowej to rola aktora stosunków ekonomicznych oraz rola aktora stosunków politycznych i kulturowych. Od ponad pięćdziesięciu lat Unia Europejska funkcjonuje w świecie, jako przykład udanej integracji ekonomicznej. Ponad 50 lat temu w ówczesnych krajach członkowskich zaczęto znosić wszelkie bariery, które powstrzymywały wolny przepływ dóbr, usług, kapitału oraz ludzi w celu stworzenia strefy dobrobytu i bezpieczeństwa. Osiągnięciami Unii na polu ekonomicznym są przede wszystkim wielkie projekty, które zakończyły się sukcesem, czyli stworzenie unii celnej, następnie powstanie Jednolitego Rynku Europejskiego oraz tworzenie Unii Gospodarczo-Walutowej. Od 1993 r. Jednolity Rynek Europejski stworzył możliwości wolnego przepływu tak szerokie, jakby chodziło o jeden kraj. Jed-

${ }^{10}$ R. Zięba, Unia Europejska jako aktor stosunków międzynarodowych, Warszawa 2003, S. 245 .

${ }^{11}$ Tamże, s. 259. 
nocześnie dopełnieniem tego jest strefa Schengen. Według Komisji Europejskiej, Jednolity Rynek Europejski od 1993 r. umożliwił stworzenie 2,5 miliona nowych miejsc pracy. Obecny kryzys w Europie mocno oczywiście dotknął Europę, ale, jak dotąd, nie zachwiał samą konstrukcją JRE ${ }^{12}$.

Do tego dochodzi jeszcze rola Unii Europejskiej jako potężnego donatora pomocy rozwojowej. Ponad połowa środków na świecie wydawanych na pomoc dla krajów najbiedniejszych pochodzi z Unii Europejskiej, a także z jej krajów członkowskich. Dlatego też Unia Europejska jest uznawana za największego ofiarodawcę pomocy na świecie. Głównym celem Unii Europejskiej w zakresie rozwoju jest wyeliminowanie ubóstwa i dokonanie tego w sposób zrównoważony. Kluczową rolą w polityce unijnej, dotyczącej rozwoju jest realizacja celów milenijnych, przyjętych przez światowych przywódców w roku 2000, którymi są m.in.: zmniejszanie skrajnego ubóstwa, ograniczanie rozprzestrzeniania się AIDS oraz zapewnianie powszechnego nauczania na poziomie podstawowym. Bardzo ważna jest też pomoc w ramach układów handlowych udzielana przez Unię Europejską krajom najsłabiej rozwiniętym. W zasadzie Unia Europejska jako blok handlowy w tej chwili nie stosuje ceł i kontyngentów dla produktów (wszystkich oprócz broni), które pochodzą z tych krajów. Funkcjonują tutaj specjalne stosunki handlowe pomiędzy Unią Europejską a krajami zrzeszonymi w grupie państw Afryki, Karaibów i Pacyfiku. Unia Europejska systematycznie opracowuje i wprowadza w życie szereg umów o partnerstwie gospodarczym z tymi krajami. Naczelną ideą tych umów jest wspieranie objętych nimi krajów w integracji $\mathrm{z}$ sąsiadami w regionie, tak, aby czynić kroki ku globalnej integracji ${ }^{13}$.

W 2008 r. Unia Europejska wraz ze swymi państwami członkowskimi udzieliły krajom rozwijającym się pomocy rozwojowej w wysokości ponad 49 mld euro. Jest to odpowiednik 0,40 proc. PNB państw członkowskich i przewyższa wielkość pomocy udzielanej przez USA oraz przez Japonię. Przelicznik ten zakładany na rok 2010 to 0,56 proc. PNB, natomiast w 2015 r. ma to być 0,7 proc. Pomoc Unii Europejskiej dla krajów rozwijających się jest udzielana w przeważnej mierze w postaci bezzwrotnych dotacji. Ale także Europejski Bank Inwestycyjny udziela uprzywilejowanych pożyczek oraz udostępnia kapitał inwestycyjny. Unia Europejska propaguje także różne strategie samopomocy, a także strategie zwalczania ubóstwa, tak, aby umożliwiać krajom rozwijającym się umacnianie procesu demokratyzacji, rozbudowywanie programów społecznych, rozwój własnych instytucji, zwiększanie możliwości właściwego działania sektorów publicznego i prywatnego, zapewnienie przestrzegania praw człowieka $\mathrm{z}$ uwzględnieniem równości kobiet i mężczyzn ${ }^{14}$.

Niektórzy badacze podważają takie podziały ról międzynarodowych dla Unii Europejskiej, uznając, że aktywna dyplomacja, na przykład, jest środkiem do

\footnotetext{
${ }^{12}$ Eurostat, Europe in figures, Eurostat Yearbook 2009, s. 65.

${ }^{13}$ Patrz rozwój, www.europa.eu.

${ }^{14}$ Tamże.
} 
realizacji wielu ról międzynarodowych. P. Borkowski uważa, że już samo posiadanie instrumentów dyplomatycznych może być w przypadku Unii Europejskiej uznane za osiągnięcie samo w sobie. Podaje on swój własny spis ról międzynarodowych dla Unii Europejskiej, który wygląda następująco:

- Unia Europejska odgrywa rolę centrum współczesnych stosunków międzynarodowych i bieguna przyciągania;

- Unia Europejska odgrywa rolę mocarstwa normatywnego. Reprezentuje ona model organizacji życia społecznego i politycznego wewnątrz państw. Kluczową rolę w tym miejscu odgrywają wartości reprezentowane przez Unię Europejską;

- Unia Europejska odgrywa rolę stabilizatora politycznego ${ }^{15}$.

Zwłaszcza w odniesieniu do ostatniego spisu ról politycznych należy stwierdzić, że jest on nader trafny, ukazując wielkość i siłę ciężkości tak dużego organizmu integracyjnego, jakim jest Unia Europejska. Jednocześnie nie może umknąć uwagi fakt, że rola centrum odgrywanego we współczesnych stosunkach międzynarodowych nie musi odnosić się tylko do stosunków politycznych czy też kulturowych. Może ona być także zastosowana w odniesieniu do stosunków ekonomicznych.

\section{Europejska Polityka Sąsiedztwa jako instrument oddziaływania Unii Europejskiej na jej pogranicze}

W marcu 2003 r. Komisja Europejska przedstawiła komunikat „Szersza Europa - sąsiedztwo: nowe ramy stosunków z naszymi wschodnimi i południowymi sąsiadami" ${ }^{16}$.W czerwcu 2003 r. Rada Unii Europejskiej uznała ten komunikat za dobrą podstawę do stworzenia nowych zasad polityki wobec tych krajów i zaprezentowała powszechne cele i zasady oraz formy polityczne i gospodarcze współpracy Unii Europejskiej z przyszłymi sąsiadami po rozszerzeniu UE. Postanowienia Rady Unii Europejskiej zostały zatwierdzone na szczycie Unii Europejskiej w Salonikach w czerwcu 2003 r. W lipcu 2003 r. Komisja opublikowała komunikat „Torując drogę nowemu instrumentowi sąsiedztwa”, w którym przedstawiła Programy Sąsiedztwa na lata 2004-2006. Programy Sąsiedztwa miały być instrumentami usprawniającymi współpracę w zakresie stosowanych programów pomocowych Unii Europejskiej przez państwa sąsiedzkie i członkowskie, tj.: PHARE, TACIS, INTERREG. W swoim zakresie działalności Komisja podjęła prace mające na celu opracowanie koncepcji nowego instrumentu pomocowego po $2006 \mathrm{r}$. dla regionów krajów sąsiadujących z rozszerzoną Unią, tzw. Instrumentu Nowego

${ }^{15}$ P. J. Borkowski, Polityka Sasiedztwa Unii Europejskiej, Warszawa 2009, s. 27.

${ }^{16}$ Szersza Europa - sąsiedztwo: nowe ramy stosunków z naszymi wschodnimi i poludniowymi sqasiadami, COM (2003) 104, 11.03.2003. 
Sąsiedztwa. W komunikacie opracowanym przez Komisję przedstawiono koncepcję utworzenia kolejnych podstaw prawnych kooperacji Unii Europejskiej z sąsiadami w ramach tzw. Europejskich Porozumień Sąsiedzkich. Komisja skierowała również swoją uwagę na kwestię przyjęcia Planów Działania opartych na wspólnych zasadach i wynikających z różnego stopnia relacji Unii Europejskiej z danymi krajami, ich potrzeb oraz zakresu wspólnych interesów. Ważną kwestią rozwoju współpracy z sąsiadami Unii Europejskiej miał być monitoring postępów w realizacji Planów Działania sprawowany przez Komisję Europejską ${ }^{17}$.

W opracowanym komunikacie z lipca 2003 r. Komisja przedstawiła koncepcję utworzenia Europejskiego Instrumentu Sąsiedztwa, który stanowił jeden z sześciu instrumentów finansowych w płaszczyźnie stosunków zewnętrznych po 2006 r., w ramach którego będą realizowane projekty współpracy transgranicznej. Programy Sąsiedztwa na lata 2004-2006 zostały zastąpione przez Europejski Instrument Sąsiedztwa. Ten instrument skierowany został m.in. do państw Zachodnich Bałkanów. Europejski Instrument Sąsiedztwa dotyczył finansowania dwóch rodzajów współpracy: transgranicznej (tzw. Window One) oraz transnarodowej (tzw. Window Two). Window One dotyczył regionów przygranicznych, czyli leżących wzdłuż granic zarówno lądowych, jak i morskich, natomiast Window Two objął całe terytoria krajów członkowskich oraz wybrane części obszarów państw partnerów w Unii Europejskiej ${ }^{18}$.

12 maja 2004 r. Komisja Europejska wraz z Wysokim Przedstawicielem ds. Wspólnej Polityki Zagranicznej i Bezpieczeństwa opublikowała komunikat dotyczący Europejskiej Polityki Sąsiedztwa, „Europejska Polityka Sąsiedztwa - Strategia". W dokumencie tym pojawiła się strategia Unii Europejskiej wobec jej sąsiadów, która stanowi kontynuację i rozwinięcie koncepcji Szerszej Europy, której założenia programowe zostały przedstawione przez Komisję Europejską w marcu 2003 r. ${ }^{19}$

Komunikat z 12 maja 2004 r. został przyjęty przez Radę Europejską, a termin „Szersza Europa” zmieniono na Europejską Politykę Sąsiedztwa. Europejska Polityka Sąsiedztwa adresowana została do państw Europy Wschodniej (Mołdawia, Ukraina, Białoruś) państw Basenu Morza Śródziemnego (Maroko, Algieria, Tunezja, Libia, Egipt, Izrael, Jordania, Liban, Syria oraz Autonomia Palestyńska), a także zostały nią objęte państwa regionu Południowego Kaukazu (Gruzja, Armenia i Azerbejdżan $)^{20}$.

W ramach Europejskiej Polityki Sąsiedztwa stworzone zostały Plany Działania dla poszczególnych krajów, w których zostały ujęte najważniejsze zagadnienia. Najistotniejszym z nich jest kooperacja w zakresie negocjacji z krajami partnerskimi w sferze określenia celów współpracy. W ramach głównych celów

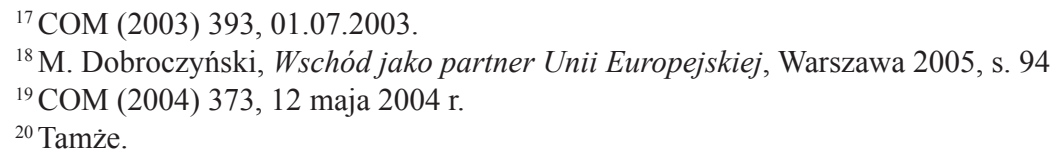


Planów Działania zwrócono uwagę na poszczególne kwestie m.in.: rozwijanie dialogu politycznego w kwestii walki z terroryzmem, zakaz proliferacji broni masowego rażenia oraz rozstrzyganie konfliktów regionalnych, a także współpracę gospodarczą i społeczną, oferując pomoc sąsiadom. Jest to pomoc przejawiająca się w stwarzaniu możliwości udziału w rynku wewnętrznym Unii Europejskiej wraz $\mathrm{z}$ pełną harmonizacją prawa, udział w unijnych programach dotyczących edukacji, szkoleń, badań naukowych, szersze możliwości zacieśnienia związków z Unią Europejską w dziedzinie komunikacji i przepływu technologii, a także dalszy rozwój infrastruktury energetycznej i transportowej. W dziedzinie handlu polityka sąsiedztwa zmierza do otwarcia rynków zgodnie z regułami Światowej Organizacji Handlu oraz wymaganymi standardami UE. Duży nacisk kładzie na rozwój kooperacji w zakresie spraw wewnętrznych i wymiaru sprawiedliwości, a w przypadku granic na eliminowanie nielegalnej migracji, handlu ludźmi i zorganizowanej przestępczości ${ }^{21}$.

Europejska Polityka Sąsiedztwa podkreśla, że wzajemne relacje z sąsiadami mają opierać się na wspólnych wartościach, zasadach dobrego rządzenia (good governance), prawach człowieka oraz muszą być oparte o reguły wolnego rynku i zrównoważonego rozwoju. Plany Działania stanowiły pierwszą fazę kształtowania nowej polityki sąsiedztwa, które oceniały potencjał i potrzeby pogłębiania

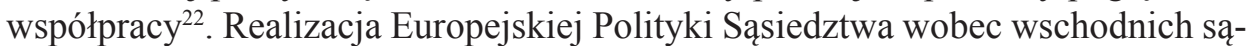
siadów w celu wzajemnej współpracy realizowana jest na mocy Umów o Partnerstwie i Współpracy (Partnership and Cooperation Agreement - PCA). Umowy te dotyczą wszystkich państw wschodniego sąsiedztwa z wyjątkiem Białorusi. W oparciu o te umowy działania polityki sąsiedztwa były regulowane i opierane o Plany Działania ${ }^{23}$.

W komunikacie z 4 grudnia 2006 r. Komisja Europejska przedstawiła nowe propozycje dotyczące wzmocnienia i rozwoju Europejskiej Polityki Sąsiedztwa wobec jej sąsiadów. W ciągu osiemnastu miesięcy realizacji Europejskiej Polityki Sąsiedztwa odnotowano pozytywne skutki. W kolejnym komunikacie Komisja proponuje rozszerzenie zależności tej polityki od wprowadzania reform w krajach, które są gotowe na ich przyjęcie. W komunikacie zostały przedstawione sprawozdania z postępów poczynionych przez kraje objęte polityką sąsiedztwa, które przyjęły Plany Działań EPS w 2005 r., takie jak Ukraina, Mołdawia, Izrael, Jordania, Autonomia Palestyńska, Tunezja i Maroko. Ten komunikat koncentruje się na kwestiach współpracy między narodami, umacniania stosunków handlowych, silnej kooperacji związanej z energią, migracją i wizami, a także wsparcia finansowego ${ }^{24}$.

${ }^{21}$ Tamże.

${ }^{22}$ M. Krzysztofowicz, Polska i Białoruś po rozszerzeniu Unii Europejskiej, Warszawa 2005, s. 58.

${ }^{23}$ Tamże, s. 92.

${ }^{24}$ J. Maliszewska-Nienartowicz, Europejska Polityka Sasiedztwa: cele i instrumenty, „Sprawy Międzynarodowe", 3/2007, s. 71. 


\section{Europejska Polityka Sąsiedztwa na południowym Kaukazie}

Nawiązanie relacji Armenii z państwami Unii Europejskiej nastąpiło w wyniku rozpadu Związku Radzieckiego i po powstaniu tego państwa w 1991 r. Krokiem w zacieśnianiu stosunków między Unią Europejską a Armenią było podpisanie w roku 1999 Układu o Partnerstwie i Współpracy (UPW). W 2001 r. kraj ten stał się pełnoprawnym członkiem Rady Europy, a w 2003 r. Armenia wstąpiła do WTO, co wskazywało na postępy przeprowadzanych reform. Rząd stanął wtedy przed obliczem wprowadzania koniecznych zmian w państwie, nie tylko w gospodarce, ale także w dziedzinie demokracji i praw człowieka. Wynikało to z wykonywania zobowiązań członka Rady Europy i OBWE. Bardzo istotne były reformy gospodarcze, modyfikacja systemu podatkowego i celnego, co wpływało na poprawę koniunktury i na rozwój inwestycji. Niezbędną była także restrukturyzacja sektora energetycznego. Jako problem bardzo poważny jest traktowana kwestia konfliktu z Azerbejdżanem o Górski Karabach ${ }^{25}$.

W ramach Europejskiej Polityki Sąsiedztwa Unia Europejska i Armenia przyjęły w 2005 r. Plan Działania dla tego kraju. Jest on zdefiniowany jako dokument polityczny, który wyznacza strategiczne cele współpracy pomiędzy Armenią a Unią Europejską. Ramy czasowe jakie przyjęto dla tego dokumentu to 5 lat. Implementacja tego planu ma pomóc wypełniać warunki UPW z 1999 r. Jako cel strategiczny przyjmuje się w tym Planie dla Armenii pomoc dla tego kraju w głębszej integracji z Europejskim obszarem ekonomicznym i społecznym. Unia Europejska liczy na to, że Plan pomoże Armenii osiągnąć uregulowania, normy i standardy podobne, jak w Unii Europejskiej, a to pomoże zbudować fundamenty mocniejszej integracji Armenii z Unią, a także pomoże krajowi osiągnąć wzrost ekonomiczny, spójność społeczną i zainicjuje budowę standardów ochrony środowiska ${ }^{26}$.

Plan Działania dla Armenii przedstawia następujące perspektywy dla tego kraju:

- dużo miejsca poświęca możliwościom pogłębienia integracji Armenii z Unią Europejską. Jest on traktowany jako pokazanie możliwości uczestnictwa Armenii w różnych aspektach Jednolitego Rynku Europejskiego, wskazuje on także na możliwości uczestnictwa w wybranych programach unijnych;

- akcentuje możliwości rozwinięcia mechanizmów dialogu politycznego;

- kładzie duży nacisk na kontynuację zobowiązań w sprawie rozwiązywania kwestii konfliktu o Górski Karabach w oparciu o konsultacje i zalecenia OBWE;

- Plan Działania mówi o pogłębianiu relacji handlowych i ekonomicznych, o wzajemnym otwarciu gospodarczym. W tym kontekście mówi o kontynuacji redukcji barier pozacelnych dla handlu;

${ }^{25}$ Komunikat Komisji do Rady, Europejska Polityka Sąsiedztwa Zalecenia dla Armenii, Azerbejdżanu, Gruzji oraz dla Egiptu i Libanu, COM (2005) 72 wersja ostateczna, Bruksela, 2.3.2005 r.

${ }^{26}$ EU/Armenia Action Plan, www. europa. eu/european neighbourhood policy. 
- Plan Działania zakłada bardzo poważne wsparcie finansowe, którego głównym narzędziem jest Europejski Instrument Sąsiedztwa i Partnerstwa;

- Plan Działania mówi o uczestnictwie w wybranych programach wspólnotowych, związanych z promocją wolności gospodarczych, kultury, edukacji, ochrony środowiska oraz badań naukowych;

- Plan ten przewiduje wsparcie techniczne w ramach dostosowywania się Armenii do aquis Unii, w ramach tego wsparcia zezwala się Armenii na korzystanie ze współpracy z Biurem Wymiany Informacji o Pomocy Technicznej (TAIEX);

- Unia przewiduje także dialog w kwestii przemieszczania się ludzi, zarządzania migracjami i ruchu wizowego ${ }^{27}$.

Plan Działania dla Armenii wyznacza osiem obszarów priorytetowych:

1) Obszar Priorytetowy 1: Wzmacnianie struktur demokratycznych i standardów prawnych ze szczególnym naciskiem na reformę sądownictwa;

2) Obszar Priorytetowy 2: Wzmacnianie ochrony praw człowieka i podstawowych wolności w odniesieniu do międzynarodowych umów, które ratyfikowała Armenia;

3) Obszar Priorytetowy 3: Wzmacnianie rozwoju gospodarczego, ochrony środowiska i w dłuższej perspektywie zasad zrównoważonego rozwoju;

4) Obszar Priorytetowy 4: Poprawa klimatu inwestycyjnego;

5) Obszar Priorytetowy 5: Głębsza konwergencja między uregulowaniami gospodarczymi w odniesieniu do międzynarodowych standardów a praktyką administracyjną;

6) Obszar Priorytetowy 6: Opracowanie i rozwój nowej strategii energetycznej związanej z dywersyfikacją źródeł energii, zamknięciem elektrowni jądrowej w Medzamor oraz wdrożeniem strategii zarządzania odpadami radioaktywnymi;

7) Obszar Priorytetowy 7: Pokojowe rozwiązania dla konfliktu o Górski Karabach;

8) Obszar Priorytetowy 8: Współpraca regionalna ${ }^{28}$.

Sytuacja polityczna Azerbejdżanu jest bardzo zbliżona do Armenii. Relacje pomiędzy państwami członkowskimi Unii Europejskiej a Azerbejdżanem opierały się na sytuacji wynikającej z rozpadu ZSRR, powstania tego państwa w $1991 \mathrm{r}$. W tle był konflikt z Armenią o Górski Karabach i niestabilna sytuacja wewnętrzna. W 1999 r. Azerbejdżan podpisał Układ o Partnerstwie i Współpracy (UPW), co wpłynęło na kształtowanie się stosunków między Unią Europejską a tym państwem. Zasadniczym priorytetem dla tego kraju, z punktu widzenia Unii, jest przede wszystkim państwo prawa, inicjowanie demokratycznych mechanizmów, walka z korupcją, ochrona praw człowieka, zobowiązania, które Azerbejdżan musi wypełniać wobec Rady Europy i OBWE. W odniesieniu do gospodarki najważniejszym elementem jest poprawa klimatu inwestycyjnego i zróżnicowanie działalności gospodarczej ${ }^{29}$.

\footnotetext{
${ }^{27}$ Tamże.

${ }^{28}$ Tamże.

${ }^{29}$ J. Barcz, Integracja Europejska, Warszawa 2007, s. 350.
} 
Również Plan Działania dla Azerbejdżanu przyjęty dla tego kraju w ramach Europejskiej Polityki Sąsiedztwa jest w swym schemacie zbliżony do Planu Działania przyjętego dla Armenii. Przedstawia on następujące perspektywy dla tego kraju:

- Plan Działania przedstawia perspektywę pogłębiania stopnia integracji Azerbejdżanu z Unią Europejską, a także stopniowe uczestnictwo tego kraju w kluczowych aspektach polityk unijnych, a także w programach unijnych;

- Kolejną perspektywą, podobnie jak w przypadku Armenii, jest przedstawienie perspektywy rozwijania i intensyfikacja dialogu politycznego;

- Następna perspektywa jest także tożsama z Planem Działania Armenii, mianowicie jest to wsparcie dla działań związanych z porozumieniami w sprawie Górskiego Karabachu;

- Plan Działania dla Azerbejdżanu przewiduje pogłębianie relacji handlowych i gospodarczych między Unią Europejską a powyższym państwem;

- Unia także tutaj przedstawia propozycje uczestnictwa w działaniach Instrumentu Europejskiego Partnerstwa i Sąsiedztwa;

- Plan ten zakłada również perspektywy stopniowego otwierania możliwości uczestnictwa w programach unijnych, promujących kulturę, edukację oraz ochronę środowiska;

- Podobnie jak w przypadku Armenii, Plan Działania zakłada techniczne możliwości uczestnictwa Azerbejdżanu w pracach TAIEX ${ }^{30}$.

Plan Działania dla Azerbejdżanu przewiduje następujące priorytety:

1) Obszar Priorytetowy 1: Umacnianie wszystkich pokojowych poczynań dotyczących rozwiązania konfliktu o Górski Karabach;

2) Obszar Priorytetowy 2: Wzmacnianie procedur demokratycznych, włączając w to przejrzyste procedury wyborcze;

3) Obszar Priorytetowy 3: Wzmacnianie wsparcia dla ochrony praw człowieka i podstawowych wolności oraz zasad przestrzegania praw międzynarodowych i dotrzymywania umów podpisanych przez Azerbejdżan;

4) Obszar Priorytetowy 4: Poprawa klimatu biznesowego i inwestycyjnego, w tym punkcie jest szczególny akcent położony na walkę z korupcją;

5) Obszar Priorytetowy 5: Lepsze dostosowanie procedur celnych do norm i standardów międzynarodowych, w tym UE;

6) Obszar Priorytetowy 6: Zrównoważony rozwój ekonomiczny, czyli dywersyfikacja gospodarki, rozwój obszarów wiejskich, redukcja obszarów ubóstwa, a także wzmacnianie przepisów i standardów dotyczących ochrony środowiska;

7) Obszar Priorytetowy 7: Większa zbieżność pomiędzy przepisami związanymi z gospodarką a procedurami administracyjnymi;

8) Obszar Priorytetowy 8: Wzmacnianie dwustronnej współpracy Unii Europejskiej i Azerbejdżanu w zakresie energetyki;

${ }^{30}$ EU/Azerbaijan Action Plan, www.europa.eu/european neighbourhood policy. 
9) Obszar Priorytetowy 9: Wzmacnianie współpracy na polu sprawiedliwości, wolności i bezpieczeństwa, włącznie ze skutecznym zarządzaniem granicami;

10) Obszar Priorytetowy 10: Wzmacnianie współpracy regionalnej ${ }^{31}$.

Gruzja, trzeci lub, patrząc od strony zachodniej, pierwszy kraj na południowym Kaukazie odzyskała niepodległość w takich samych okolicznościach, jak Armenia i Azerbejdżan. W 1991 r. w wyniku rozpadu ZSRR powstało państwo Gruzja. W 1999 r. Gruzja podpisała Układ o Partnerstwie i Współpracy (UPW), co pozwoliło na zacieśnianie relacji z Unią Europejską. Konflikty wewnętrzne, związane z próbami oderwania się republik Abchazji i południowej Osetii, oraz wynikające $z$ tego napięte relacje z Rosją od początku wzbudzały niepokój Komisji Europejskiej, jak wiemy doprowadziło to w końcu do wojny z Rosją ${ }^{32}$.

Plan Działania dla Gruzji przewiduje następujące perspektywy dla tego kraju:

- Jako pierwsza zaakcentowana jest, podobnie jak w powyższych Planach, perspektywa głębszej integracji i szerszego uczestnictwa Gruzji w Jednolitym Rynku Europejskim;

- Druga perspektywa jest taka sama, jak w Planach Działań pokazanych powyżej. Jest to rozwój mechanizmów dialogu politycznego;

- Również i w tym Planie jest pokazany problem utrzymania dialogu w celu pokojowego rozwiązania wewnętrznych konfliktów Gruzji;

- Przedstawiana jest także perspektywa wzmocnienia współpracy w zakresie sprawiedliwości, wolności i bezpieczeństwa, w szczególności na polu zarządzania granicami i migracjami;

- Wzrastające możliwości bliższej współpracy na polu polityki zagranicznej i bezpieczeństwa, obejmując tym także Europejską Politykę Bezpieczeństwa i Obrony, w szczególności w kwestiach stabilizacji regionu i zarządzania kryzysowego;

- Pogłębianie relacji gospodarczych i handlowych, zapewniających większą zbieżność reguł prawnych w gospodarce z praktyką administracyjną. A prócz tego otwarcie gospodarcze na siebie nawzajem, kontynuacja redukcji pozacelnych barier handlowych, które będą stymulować i inwestycje, i wzrost gospodarczy;

- Plan Działania przewiduje także perspektywę wzmacniania współpracy na polu energii, transportu i środowiska, które mają się przyczynić do wzrostu bezpieczeństwa energetycznego oraz do wzrostu dywersyfikacji energetycznej dla potrzeb Unii Europejskiej;

- Plan mówi o perspektywie rozwoju współpracy równoległej, obok partnerstwa na południowym Kaukazie, przewiduje wzmacnianie dwustronnej i wielostronnej współpracy w rejonie Morza Czarnego i idzie dalej, roztaczając perspektywę włączenia w to współpracy między regionami Mórz: Bałtyckiego, Czarnego oraz Kaspijskiego;

${ }^{31}$ Tamże.

32 Komunikat Komisji do Rady, Europejska Polityka Sąsiedztwa Zalecenia dla Armenii, Azerbejdżanu, Gruzji oraz dla Egiptu i Libanu... 
- Plan przewiduje perspektywę identyfikacji potrzeb w zakresie inicjatyw lokalnych, które muszą być podjęte szczególnie w odniesieniu do zasad dobrego rządzenia;

- Plan Działania dla Gruzji określa także wsparcie finansowe. Umożliwia Gruzji uczestnictwo w Europejskim Instrumencie Partnerstwa i Sąsiedztwa, szczególnie w zakresie współpracy transgranicznej i transnarodowej;

- Dokument stwierdza, że Gruzja będzie miała możliwości uczestnictwa w niektórych programach unijnych, dotyczących promocji kultury, edukacji, środowiska oraz współpracy naukowej;

- Wsparcie zostanie także udzielone Gruzji na poziomie instrumentów TAIEX w zakresie wprowadzania norm i standardów unijnych;

- Dokument przewiduje również dialog w odniesieniu do przepływu ludzi pomiędzy Gruzją a Unią Europejską ${ }^{33}$.

Plan Działania dla Gruzji przewiduje następujące obszary priorytetowe:

1) Obszar Priorytetowy 1: Wzmacnianie zasad i standardów prawnych poprzez reformę systemu sprawiedliwości oraz instytucji państwowych. Wzmacnianie instytucji i procedur demokratycznych. Promowanie praw człowieka i podstawowych wolności. Wypełnianie przez Gruzję ratyfikowanych przez to państwo umów i porozumień z instytucjami międzynarodowymi;

2) Obszar Priorytetowy 2: Poprawa klimatu biznesowego i inwestycyjnego, problem transparentności procesu prywatyzacji i walka z korupcją;

3) Obszar Priorytetowy 3: Wzmacnianie rozwoju gospodarczego, zwiększanie wysiłku na rzecz likwidacji obszarów ubóstwa, wzmacnianie spójności społecznej, promowanie zrównoważonego rozwoju z włączeniem ochrony środowiska, zwiększanie spójności między przepisami gospodarczymi a praktyką administracyjną;

4) Obszar Priorytetowy 4: Wzmacnianie kooperacji na polu sprawiedliwości, wolności i bezpieczeństwa włącznie z zarządzaniem granicami;

5) Obszar Priorytetowy 5: Wzmacnianie współpracy regionalnej;

6) Obszar Priorytetowy 6: Promocja pokojowych rozwiązań dotyczących konfliktów wewnętrznych;

7) Obszar Priorytetowy 7: Współpraca w zakresie Polityki Zagranicznej i Bezpieczeństwa;

8) Obszar Priorytetowy 8: Współpraca w zakresie transportu i energii.

\section{Ocena efektywności Europejskiej Polityki Sąsiedztwa na przykładzie południowego Kaukazu}

W 2008 r. Unia Europejska oceniała Europejską Politykę Sąsiedztwa w dużej mierze jako udane przedsięwzięcie, aczkolwiek wymagające wzmocnienia wie-

${ }^{33}$ EU/Georgia Action Plan, www. europa.eu/european neighbourhood policy. 
lu działań podejmowanych w jej ramach. I tak, komunikat Komisji Europejskiej dotyczący Europejskiej Polityki Sąsiedztwa z grudnia 2007 r. stwierdza, że EPS pogłębia relacje pomiędzy Unią Europejską a jej sąsiadami, ustanawia odpowiednie narzędzia do ich realizacji w krajach objętych tą polityką. Komisja w tym komunikacie ciągle podtrzymuje główne założenie, z którego wynika, że Unia Europejska widzi swój najgłębszy interes w pogłębianiu rozwoju gospodarczego, stabilizacji i lepszego zarządzania we wszystkich krajach objętych polityką EPS. Unia Europejska czuje się w tym momencie aktorem, który ma rozszerzać strefę pokoju i stabilności oraz rozwoju wokół siebie. Komisja uważa, że zapobiega to sztucznym podziałom oraz stwarza nowe możliwości zarówno dla Unii Europejskiej, jak i dla jej sąsiadów objętych EPS. Komisja charakteryzuje EPS jako partnerskie narzędzie, które działa według zasady „more for more”, czyli większe im więcej inicjatyw i zaangażowania oraz zmian ze strony państw partnerskich objętych EPS, tym większe zaangażowanie i otwarcie Unii Europejskiej i większe jej zbliżenie do krajów partnerskich ${ }^{34}$.

Komisja uważa, że na tak wczesnym etapie EPS można ocenić jako dobre narzędzie, ale potrzebuje ona głębszego wsparcia, aby uczynić ją bardziej efektywną. I tak, Komisja uważa, że trzeba wdrożyć następujące działania w ramach EPS:

- wymaga ona głębszego partnerskiego zbliżenia na polu politycznym;

- należy podjąć szereg bardzo konkretnych działań obliczonych na konkretny polityczny efekt;

- Komisja stwierdza, że zewnętrzne polityki Unii muszą być mocniej zaangażowane we wdrażanie EPS ${ }^{35}$.

Gdzie poczyniono postępy? Otóż, przede wszystkim Komisja bardzo pozytywnie ocenia następujące inicjatywy:

- pozytywnie oceniono alokacje i efekty ułatwień w zarządzaniu (Governance Facility);

- podówczas tworzenie się Sąsiedzkiego Mechanizmu Inwestycyjnego;

- inicjatywy regionalnego wymiaru wschodniego związanego z Synergią Czarnomorską.

Jednakże na koniec tych pozytywnych akcentów Komisja stwierdza, że w większości krajów objętych EPS zapotrzebowanie na przeprowadzenie reform politycznych i gospodarczych jest ogromne ${ }^{36}$.

Komunikat Komisji odnoszący się do Gruzji i Armenii stwierdzał podówczas, że istnieją możliwości prowadzenia rozmów i bliższego przyjrzenia się warunkom odnośnie do zawierania porozumień z tymi krajami w celu zawierania szczegółowych porozumień odnośnie do handlu, w szczególności odnośnie do porozumień dotyczących przepisów sanitarnych i fitosanitarnych. Unia wyrażała

${ }^{34}$ Komunikat Komisji Europejskiej A Strong European Neighbourhood Policy, Bruksela, 05.12.2007, COM (2007) 774 final.

${ }^{35}$ Tamże.

${ }^{36}$ Tamże. 
także nadzieję, że nadal będzie postępować wzmacnianie współpracy pomiędzy Unią a krajami sąsiedzkimi. Komisja koncentruje się zwłaszcza na wzmacnianiu współpracy z instytucjami europejskimi, takimi jak Europejskie Biuro Patentowe. Komisja chce także wpierać dialog typu „biznes to biznes”, a także wspierać poprawę klimatu inwestycyjnego. W odniesieniu do Gruzji, Armenii i Azerbejdżanu Komisja mówiła także o zwiększeniu wysiłków na rzecz zakończenia „zamrożonych” konfliktów, takich jak konflikt w Południowej Osetii czy też o Górski Karabach. Oczywiście wiadomo doskonale, że ten pierwszy rozgorzał na nowo w $2008 \mathrm{r}^{37}$

Komisja popiera w dokumencie takie inicjatywy jak Deklaracja z Baku, po to, aby regiony Morza Czarnego, Kaspijskiego, południowego Kaukazu, a także Azji Centralnej uczynić miejscem prowadzenia dużych przedsięwzięć energetycznych transportowych i innych związanych z gospodarką i infrastrukturą, ale także regionem dialogu międzykulturowego. Komisja ceni także inicjatywę Memorandum o strategicznym partnerstwie energetycznym pomiędzy Unią Europejską a Azerbejdżanem. Memorandum to daje podstawy dla dużego projektu, dzięki któremu kaspijski gaz będzie transportowany na rynek Unii Europejskiej ${ }^{38}$.

Z powyższego widać, że bardzo ważne dla Unii jest partnerstwo i pogłębianie kooperacji na takich polach, jak energetyka, a także transport oraz zrównoważony rozwój w obszarze sąsiedzkim.

\section{Stworzenie Partnerstwa Wschodniego}

Partnerstwo Wschodnie jest nową strategią Unii Europejskiej na Wschodzie. Inicjatorami Partnerstwa Wschodniego są Polska i Szwecja, które w maju 2008 r. zaproponowały pogłębienie relacji Unii Europejskiej z państwami graniczącymi z nią od wschodu, które są objęte Europejską Polityką Sąsiedztwa. Partnerstwo Wschodnie zaproponowano następującym krajom: Armenii, Azerbejdżanowi, Białorusi, Gruzji, Mołdawii i Ukrainie. Inauguracja Partnerstwa Wschodniego odbyła się 7 maja w Pradze podczas czeskiej prezydencji. W ramach Partnerstwa Wschodniego zaproponowano zarówno pogłębienie współpracy dwustronnej, jak i wielostronnej. Propozycja ta jest skierowana do wszystkich powyższych partnerów. W Partnerstwie Wschodnim pogłębiona współpraca dwustronna ma obejmować następujące obszary aktywności:

37 Tamże.

${ }^{38}$ Memorandum of understanding on a Strategic Partnership between the European Union and the Republic of Azerbaijan in the Field of Energy, 7.12.2006, w: www.europe.eu/enp. Memorandum to pozwoliło na podpisanie umowy w Bukareszcie, która stała się podstawą do powstania projektu AGRI (Azerbeijan, Georgia, Romania Initiative). Projekt ten ma pozwolić na powstanie spółki z siedzibą w Bukareszcie, dzięki której będzie możliwy przesył gazu z Azerbejdżanu do Unii Europejskiej, co, z kolei, przyczyni się do dywersyfikacji dostaw i będzie krokiem do uniezależniania się od dostaw rosyjskich, www.europa.eu/energy. 
- Partnerstwo ma pogłębiać współpracę w zakresie uelastyczniania reżimu wizowego z długoterminowym celem wprowadzenia ruchu bezwizowego, a także szeroko rozumianej tematyki migracyjnej;

- Bardzo wiele uwagi w Partnerstwie Wschodnim poświęca się idei wprowadzenia pogłębionej Strefy Wolnego Handlu, która zostałaby zbudowana w oparciu o wynegocjowane wszechstronne umowy o wolnym handlu pomiędzy Unią Europejską i krajami objętymi Partnerstwem;

- Unia Europejska deklaruje swoje szerokie wsparcie dla reform sektorowych w krajach partnerskich, które byłyby zgodne ze standardami europejskimi;

- Partnerstwo akcentuje także potrzebę intensyfikacji kontaktów międzyludzkich, które byłyby realizowane poprzez poszerzone programy wymian akademickich, tworzenie platform społeczeństwa obywatelskiego, organizację seminariów oraz intensywnej współpracy i wymiany pomiędzy partnerami lokalnymi i regionalnymi;

- Partnerstwo zwraca szczególną uwagę na promocję w krajach partnerskich procesu integracji europejskiej, stworzenie nowej generacji Planów Działania uzgodnionych z każdym z krajów partnerskich, z jasnymi wyznacznikami do osiągnięcia, powiązanymi z dostosowaniem do standardów i norm obowiązujących w Unii Europejskiej;

- Partnerstwo mówi także o umowach zastępujących i wykraczających poza obecne umowy o partnerstwie i współpracy (PCA) ${ }^{39}$.

Partnerstwo Wschodnie, jak już wspomniano wyżej, obejmuje wszystkie kraje członkowskie Unii Europejskiej z jednej strony, a Ukrainę, Mołdowę, Azerbejdżan, Armenię, Gruzję i Białoruś z drugiej strony. Obecność na liście zwłaszcza tego ostatniego kraju jest dużą nowością, ponieważ Białoruś do tej pory nie została objęta żadną z inicjatyw wielostronnych Unii Europejskiej. Unia chce rozwijać współpracę na szczeblu technicznym i eksperckim tak, aby otworzyć możliwość włączenia do współpracy różnych grup społecznych, takich jak młodzież czy też mali i średni przedsiębiorcy. Partnerstwo jest bardzo mocno zorientowane na projekty, współpraca w ramach Partnerstwa ma być zawsze oparta na realizacji konkretnych projektów. Środki finansowe mają być zapewnione z funkcjonujących już linii budżetowych, a struktura instytucjonalna jak najbardziej ograniczona i ma służyć jak najlepiej realizacji wyznaczonych celów ${ }^{40}$.

Dlatego też sfery współpracy można podzielić na następujące obszary tematyczne:

I. Obszar polityczny i bezpieczeństwa, zakładający promocję demokracji, wspólnych wartości, rządów prawa, a także współpracę w polityce zagranicznej i bezpieczeństwa, w służbie cywilnej oraz w administracji samorządowej;

${ }^{39}$ B. Wojna, M. Gniazdowski (red.), Partnerstwo Wschodnie - raport otwarcia, Polski Instytut Spraw Międzynarodowych, Warszawa, maj 2009, s. 71.

${ }^{40}$ Tamże, s. 72. 
II. Obszar dotyczący granic oraz ruchu osobowego, zakładający uelastycznienie reżimu wizowego, kontrolę nad migracjami oraz rozwijanie nowoczesnej infrastruktury granicznej;

III. Obszar ekonomiczny i finansowy, który przewiduje dalsze wdrażanie reform gospodarczych, które zostały przewidziane w Planach Działania. Obszar ten ma także objąć kwestię usuwania barier handlowych pomiędzy krajami objętymi Partnerstwem i Unią Europejską. Ma on także służyć rozwijaniu sieci transportowych i teleinformatycznych, rozwijaniu współpracy energetycznej, rozwojowi turystyki. Te działania mają zmierzać do rozwoju integracji ekonomicznej sąsiednich krajów Unii;

IV. Kolejnym obszarem jest obszar środowiska. Kraje te, dzięki Partnerstwu, miałyby się włączyć w przeciwdziałanie zmianom klimatycznym, rozwijać technologie przyjazne dla środowiska oraz ekologiczną świadomość w społeczeństwie;

V. Ostatnim obszarem objętym Partnerstwem jest obszar społeczny. Jest to obszar, który stawia na rozwój takich kontaktów, jak bezpośrednie kontakty międzyludzkie, współpraca między organizacjami pozarządowymi, rozwój wspólnych programów edukacyjnych, a także wspólnych badań naukowych.

\section{Europejska Polityka Sąsiedztwa jako nowy instrument oddziaływania Unii Europejskiej na jej sąsiedztwo}

Europejska Polityka Sąsiedzka jest bardzo ,świeżym produktem” Unii Europejskiej, dlatego też trudno na razie wyrokować w sposób ostateczny, czy jest ona dla Unii użytecznym narzędziem. Perspektywa czasowa takich ocen jest z reguły nieco dłuższa. Jednak sama Unia poprzez komunikaty Komisji Europejskiej informuje o pewnych podsumowaniach. Najnowszym podsumowaniem dokonań Europejskiej Polityki Sąsiedztwa jest na pewno Komunikat Komisji Europejskiej z maja 2010 r. ,Taking Stock of the European Neighbourhood Policy”. Dokument jest pewnym podsumowaniem Europejskiej Polityki Sąsiedztwa od czasu jej powstania, czyli od 2004 r. Jest to dokument, na podstawie którego można stwierdzić, że Unia generalnie pozytywnie ocenia osiągnięcia Europejskiej Polityki Sąsiedztwa. Już na początku dokumentu Komisja z uznaniem mówi o jakości i intensywności kontaktów politycznych, które miały miejsce w ramach działań i współdziałań sąsiedzkich. Jako sztandarowe hasło pada również w dokumencie stwierdzenie, że wskutek działania EPS obroty handlowe między Unią a krajami sąsiedzkimi wzrosły dwukrotnie. Ten wzrost był możliwy dzięki temu, że w handlu w strefie sąsiedztwa postępuje proces liberalizacji i regulacji konwergencji pomiędzy UE a krajami EPS. Komisja stwierdza także, że pomoc unijna została „uszyta na miarę" w odniesieniu do reform poczynionych przez poszczególne państwa sąsiedzkie, a jej wartość wzrosła w ostatnim okresie programowania o $32 \%{ }^{41}$.

\footnotetext{
${ }^{41}$ Communication from the Commission, Taking stock of the European Neighbourhood Policy, Brussels, 12.05.2010, COM (2010) 207.
} 
W odniesieniu do wschodniego wymiaru Europejskiej Polityki Sąsiedztwa Komisja podkreśla wagę utworzenia Partnerstwa Wschodniego, które nadaje nowy wymiar Europejskiej Polityce Sąsiedztwa w odniesieniu do krajów sąsiadujących z Unią od wschodu. Jednocześnie też Komisja pozytywnie ocenia bilateralną współpracę z krajami wschodu. Współpraca ta nabiera nowego wymiaru dzięki bilateralnym porozumieniom $\mathrm{z}$ krajami zawieranym $\mathrm{w}$ ramach EPS i wzmocnionych przez Partnerstwo Wschodnie.

Komisja odnosi się też do kwestii dobrego rządzenia oraz do problematyki nieuregulowanych konfliktów. Dobre rządzenie jest przez Unię uznawane za cel, do którego powinny dążyć kraje sąsiedzkie, ale także jest uznawane za filar stabilności politycznej i wzrostu gospodarczego. W odniesieniu do problematyki konfliktów Komisja dużo uwagi poświęca Gruzji, jako państwu objętemu EPS, które, jak wiadomo, obecnie znów próbuje się ustabilizować po konflikcie z 2008 r. Gruzja w ramach Europejskiej Polityki Sąsiedztwa została objęta wsparciem dyplomatycznym Unii w momencie rozpoczęcia konfliktu sierpniowego w 2008 r., a następnie objęta wsparciem pokonfliktowym na trzech płaszczyznach: politycznej, technicznej i finansowej. Pakiet finansowy tego wsparcia opiewa na $500 \mathrm{mln}$ euro. Komisja podkreśla także aktywną rolę Unii jako strony biorącej udział wraz z ONZ i OBWE w rozmowach genewskich dotyczących rozwiązania konfliktu gruzińskiego, a także ustanowienie Misji Obserwacyjnej Unii Europejskiej (EUMM) do monitorowania przestrzegania porozumień zawartych między stronami konfliktu pod koniec sierpnia i we wrześniu 2008 r. $^{42}$

Kolejną kwestią związaną z wdrażaniem polityki sąsiedzkiej są ułatwienia wizowe. Komisja ujawnia, że w samym tylko 2008 r. wydano ponad $2 \mathrm{mln}$ wiz do strefy Schengen dla obywateli państw objętych polityką sąsiedzką. Trwają obecnie poważnie zaawansowane rozmowy na temat ułatwień związanych z uzyskiwaniem takich wiz dla obywateli Armenii, Azerbejdżanu i Gruzji ${ }^{43}$.

Komisja dużo miejsca poświęca także kwestiom integracji ekonomicznej państw EPS. Handel pomiędzy krajami Unii a krajami sąsiedzkimi wykazuje tendencję mocno wzrostową. W okresie 2004-2008 eksport UE do krajów EPS wzrósł o $63 \%$, natomiast import aż o $91 \%$. Unia proponuje tym państwom strategię dochodzenia do integracji z Jednolitym Rynkiem Europejskim związanej z wprowadzaniem ułatwień dla handlu towarami i usługami, z wprowadzaniem przepisów upraszczających tworzenie firm, wchodzenie bezpośrednich inwestycji zagranicznych oraz tworzenie wysokiego poziomu ochrony socjalnej, konsumenckiej oraz środowiska. Komisja to wszystko podsumowuje w propozycji tworzenia głębokich i wszechstronnych stref wolnego handlu na terenach państw sąsiedzkich. Miałyby to być strefy nowego typu, wykraczające poza schemat do-

42 Tamże. O rozmowach genewskich w kwestii konfliktu gruzińskiego więcej zob. J. Dziuba, Unia Europejska a Gruzja. Rok po wojnie sierpniowej, w: Analizy Natolińskie, 10 (42) 2009, natolin.edu.pl, O Misji Obserwacyjnej UE w Gruzji więcej zob. www.eumm.eu.

${ }^{43}$ Tamże. 
tychczas stosowanych stref na świecie. W odniesieniu do krajów południowego Kaukazu, to Gruzja i Armenia przygotowują się do rozpoczęcia negocjacji w tych kwestiach $^{44}$.

Komisja w swoim dokumencie wiele miejsca poświęca także kwestiom energetycznym. Unia Europejska wraz ze swoimi partnerami z sąsiedztwa chce rozwijać sieci energetyczne. Kraje południowego Kaukazu są uczestnikami takich inicjatyw, jak gazowa sieć transkaspijska, południowy korytarz gazowy, rurociąg Nabucco czy też 3 Platforma Partnerstwa Wschodniego. W odniesieniu do Armenii ciągle toczy się dialog z Unią dotyczący bezpieczeństwa elektrowni jądrowej w Mezamor. Komisja zaznacza, że kwestie energetyczne, takie jak efektywność energetyczna, współdziałanie w zakresie szeroko pojętej problematyki energetycznej czy też odnawialne źródła energii będą jednym z kluczowych obszarów działań w zakresie Europejskiej Polityki Sąsiedztwa w nadchodzącym okresie ${ }^{45}$.

\section{Zakończenie}

Region południowego Kaukazu jest regionem, w którym jak w soczewce odbijają się problemy i wyzwania współczesnego świata. Jeżeli na Ukrainę spojrzeć jako na „modelowy” kraj tak zwanego Wschodu, to widać, że i region południowego Kaukazu może być niestabilny. $Z$ drugiej strony twierdzi się, że region ten przeżywa bardzo silne impulsy europeizacji. Dlatego też szczególnie w tym regionie będzie widoczna rola i dynamika oddziaływania każdego aktora stosunków międzynarodowych, który chce być w tym regionie obecny. Wydaje się, że w odniesieniu do głównych aktorów światowych to region południowego Kaukazu jest regionem zainteresowań ze strony przynajmniej dwóch największych aktorów sceny światowej. Przede wszystkim jest to region, który jest tradycyjnie obiektem zainteresowania Rosji. Rosja może się poszczycić wielowiekową tradycją politycznego, gospodarczego i militarnego zaangażowania w tym regionie. Rosja dziś rości sobie pretensje do zwierzchnictwa wprost nad wieloma obszarami z geopolitycznego sąsiedztwa, takimi jak Białoruś, wschodnia Ukraina, Krym czy Naddniestrze. Natomiast na całym tym obszarze, z regionem południowego Kaukazu włącznie, Rosja czuje się graczem pierwszoplanowym. Stanowisko administracji Baracka Obamy jest inne niż jego poprzedników, ale niewątpliwie cały region Europy Wschodniej, Kaukazu czy Azji Środkowej nie może być całkowicie usunięty z pola zainteresowań Stanów Zjednoczonych. Niewątpliwie trzecim wielkim graczem w regionie jest Bruksela. Jej obecność jest coraz bardziej wyrazista i zauważalna. Unia Europejska poprzez to, że jest aktorem na scenie międzynarodowej coraz bardziej świadomym swojej roli bierze również polityczną oraz eko-

$\begin{array}{ll}44 & \text { Tamże. } \\ & 45 \\ & \text { Tamże. }\end{array}$ 
nomiczną odpowiedzialność za kształt swojego pogranicza. A pogranicze Unii to olbrzymi i zróżnicowany obszar. Dlatego też Unia uruchomiła poważne narzędzie do tychże oddziaływań, czyli Europejską Politykę Sąsiedztwa. Oczywiście pozostaje pytanie, na ile poprzez realizację Europejskiej Polityki Sąsiedztwa, Unia staje się poważnym aktorem w tym regionie $\mathrm{i}$ w całym swoim sąsiedztwie. Autor ryzykuje odpowiedź, że jest to kwestia pewnego upływu czasu. Tym bardziej, że jej zaangażowaniu jako aktora będą sprzyjać nowe podstawy prawne. Niewątpliwie Traktat Lizboński daje mocne podstawy prawne do takiego zaangażowania. Dlatego też pytaniem i tezą na przyszłość jest nie to, czy Unia będzie poważnym aktorem zaangażowanym w tym regionie oraz na całym swoim pograniczu, ale bardziej na ile to zaangażowanie wzrośnie i jakie będą tego skutki w stosunkach międzynarodowych w przyszłości. 